\title{
ФРАКЦИЙНИЙ СКЛАД БІЛКІВ КРОВІ КОРОПА ЗА ДІЇ НАНДРОЛОНУ ТА АЛЬБЕНДАЗОЛУ
}

\author{
I. М. Курбатова, М. О. Захаренко \\ innakurbatova@ukr.net
}

Національний Університет біоресурсів і природокористування України, вул. Героїв Оборони, 11, Київ 03041, Україна

\begin{abstract}
Вилив анаболічних стероїдів, зокрема нандролону та антигельмінтика альбендазолу на коропових риб залежить від конщентрацій у воді та пов'язаний зі зміною низки морфологічних показників і фізіолого-біохімічних механізмів у процесі їх адаптаиії до дї ксенобіотиків води, як і показали дослідження загального вмісту та фракційного складу білків плазми крові. В модельних експериментах, проведених на дворічках коропа, головною метою яких було дослідити вилив ксенобіотиків антропогенного походження на фракційний склад білків плазми крові, встановлено, що за нетривалої експозиції (72 години)

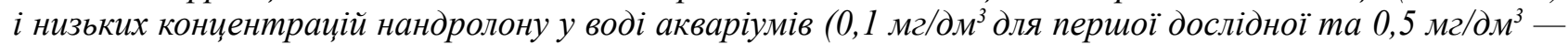
для другої дослідної групи) спостерігаються лише незначні зміни вмісту білків з молекулярною масою 25, 35-50 і 100-140 кДа за сталих значень показників інших фракиій. 3 підвищенням концентрації нандролону у воді акваріуму до 1,0 мг/дм³ вміст білків з молекулярною масою 450 кДа і вище зріс на $91 \%$, 340 кДа - на $78 \%, 260$ кДа - на $101 \%, 70$ кДа-на 149\%, 50 кДа - на $111 \%, 25-50$ кДа-35-62\% порівняно з контролем. Отже, анаболічні стероїди, потрапляючи у воду, за низьких кониентрачій не впливають, а за високих - стимулюють прочеси біосинтезу білків в тканинах дворічок коропа.

Нетривале перебування (12 годин) коропів в акваріумі з кониентраџією антигельмінтика альбендазолу у воді 0,2 мг/л змінювало лише окремі фракиії білків плазми крові риб. Збільшення концентраиії альбендазолу у воді до 0,5 мг/л і особливо до 1,0 мح/л впливало на білковий спектр плазми крові риб значною мірою, зниюуючи вміст більшості білків низько- та високомолекулярних фракиій.

Досліджувані ксенобіотики нандролон та альбендазол у вищевказаних концентраціях у воді та за нетривалої експозииії не впливали на поведінку риб, кількість дихальних рухів і на томографічні показники внутрішніх органів.

Стан зовнішніх покривів тіла, а також органолептичні показники внутрішніх органів риб дослідних груп за дії різних концентрацій нандролону та альбендазолу не відрізнялись від подібних характеристик коропів контрольної групи.

Одержані результати свідчать про важливу роль білків плазми крові риб в механізмах їх адаптації до дї ксенобіотиків води, зокрема анаболічного стероїду нандролону та антигельмінтика альбендазолу.
\end{abstract}

Ключові слова: КОРОП, ПЛАЗМА КРОВІ, БІЛКИ, НАНДРОЛОН, АЛЬБЕНДАЗОЛ

\section{FRACTIONAL COMPOSITION OF CARP BLOOD PROTEINS UNDER THE INFLUENCE OF NANDROLONE AND ALBENDAZOLE}

\author{
I M. Kurbatova, M. O. Zakharenko \\ innakurbatova@ukr.net
}

\begin{abstract}
National University of Life and Environmental Sciences of Ukraine,
11 Geroiv Oborony str., Kyiv 03041, Ukraine
\end{abstract}

The effect of anabolic steroids such as nandrolone and deworming albendazole on carp fish depends on their concentrations in the water and is associated with a change in a number of morphological, physiological and biochemical mechanisms in the process of adaptation to the effects of xenobiotics water as it was shown by studies of total and fractional composition of blood plasma protein. The model experiments carried out on the two-year carps to investigate the influence of anthropogenic xenobiotics on the fractional composition of blood plasma proteins revealed that the non-durable exposition (72 hours) and low nanrolone concentration $\left(0.1 \mathrm{mg} / \mathrm{dm}^{3}\right.$ for the first research group and $0.5 \mathrm{mg} / \mathrm{dm}^{3}$ for the second research group) in water in aquariums caused changes in protein content of molecular weight 25, 35-50, 100-140 kDai with constant rates in other fractions. With increase of nandrolone concentration in aquarium water to $1.0 \mathrm{mg} / \mathrm{dm}^{3}$ content of proteins with molecular weight of more than $450 \mathrm{kDa}$ increased by $91 \%, 340 \mathrm{kDa}-78 \%, 260 \mathrm{kDa}-101 \%, 70 \mathrm{kD}-$ 
$149 \%, 50 \mathrm{kDa}-111 \%, 25-50 \mathrm{kDa}-35-62 \%$ compared tothe control. We can make the conclusion that anabolic steroids at low concentrations in the water do not affect and at high concentrations stimulate the protein synthesis processes in tissues of carp yearlings.

Non-long stay (12 hours) of carps in the aquarium with a concentration of deworming albendazole $0.2 \mathrm{mg} / \mathrm{l}$ in water changed only some of the fractions of blood plasma protein in fish. Increase of concentrations of albendazole in water to $0.5 \mathrm{mg} / \mathrm{L}$ and particularly to $1.0 \mathrm{mg} / \mathrm{l}$ affected the protein spectrum of blood plasma in fish reducing the content of the most proteins with low and high molecular fractions.

The investigated xenobiotics nandrolone and albendazole at the indicated concentrations in the water and a short exposure did no affect the behavior of fish, the number of respiratory movements and tomographic indicators of their organs.

Status of integument and organoleptic characteristics of the organs in fish of research group under the influence of different concentrations of nandrolone and albendazole did not differ from the similar characteristics in the carps of control group.

The results suggest an important role of fish blood plasma proteins in mechanisms of their adaptation to the effects of water xenobiotics, particularly the anabolic steroid nandrolone and deworming albendazole.

Keywords: CARP, BLOODPLASMA, PROTEINS, NANDROLONE, ALBENDAZOLE

\title{
ФРАКЦИОННЫЙ СОСТАВ БЕЛКОВ КРОВИ КАРПА ПОД ВОЗДЕЙСТВИЕМ НАНДРОЛОНА И АЛЬБЕНДАЗОЛА
}

\author{
И. Н. Курбатова, Н. А. Захаренко \\ innakurbatova@ukr.net
}

Национальный университет биоресурсов и природопользования Украины, ул. Героев Обороны, 11, Киев, 03041, Украина

Влияние анаболических стероидов, в частности нандролона и антигельминтика альбендазола на карповых рыб зависит от их концентрации в воде и связано с изменением ряда морфологических показателей и физиолого-биохимических механизмов в процессе их адаптаичи к воздействию ксенобиотиков воды, как и показали исследования общего содержания и фракиионного состава белка плазмы крови. В модельных экспериментах, проведенных на двухлетках карпа, главной целью которых было исследовать влияние ксенобиотиков антропогенного происхождения на фракционный состав белков плазмы крови, установлено, что при недлительной экспозичии (72 часа) и низких конщентрациях нанролона в

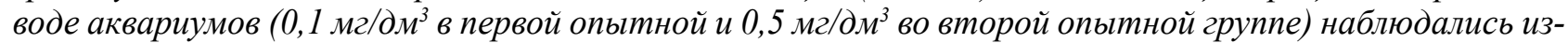
менения содержания белков с молекулярной массой 25, 35-50 и 100-140 кДа при постоянных значениях

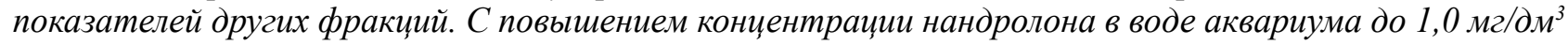
содержание белков с молекулярной массой 450 кДа и выше выросло на $91 \%, 340$ кДа - на $78 \%$, 260 кДана $101 \%, 70$ кДа - на $149 \%, 50$ кДа - на $111 \%$, 25-50 кДа - 35-62\% по сравнению с контролем. Можно сделать вывод, что анаболические стероиды, попадая в воду, при малых концентрачиях не влияют, а при високих - стимулируют процессы биосинтеза белка в тканях двухлеток карпа.

Непродолжительное пребывание (12 часов) карпов в аквариуме с концентрацией 0,2 мг/л антигельминтика альбендазола в воде изменяло только некоторые фракиии белков плазмы крови рыб. Увеличение конщентрации альбендазола в воде до 0,5 мح/л и, особенно до 1,0 мг/л, влияло на белковый спектр плазмы крови рыб в значительной степени, снижая содержание белков низко- и высокомолекулярных фракиий.

Исследуемые ксенобиотики нандролон и альбендазол при указанных конценрациях в воде и непродолжительной экспозичии не влияли на поведение рыб, количество дыхательныхх движений и на томографические показатели внутренних органов.

Состояние внешних покровов тела, а также органолептические показатели внутренних органов рыб опытных групп при воздействии разных концентраций нандролона и альбендазола не отличались от аналогичных характеристик карпов контрольной группы.

Полученные результаты свидетельствуют о важной роли белков плазмы крови рыб в механизмах их адаптачии к воздействию ксенобиотиков воды, в частности анаболического стероида нандролона и антигельминтика альбендазола.

Ключевые слова: КАРП, ПЛАЗМА КРОВИ, БЕЛКИ, НАНДРОЛОН, АЛЬБЕНДАЗОЛ 
Водні екосистеми в останній час зазнають значного антропогенного впливу, що пов'язують із потраплянням у природні водойми зі стічними водами очисних споруд цивільних об'єктів та промислових підприємств різних ксенобітиків, зокрема речовин ендокринної дії [1-3]. Значну загрозу для водних об'єктів становлять тваринницькі підприємства, які, нарощуючи виробничі потужності, накопичують значні обсяги відходів та стічних вод. 3 останніми у природні водойми потрапляє велика кількість антибіотиків та сульфаніламідних препаратів [4-6], гормони нандролон, болденон, кортикостероїди та продукти їх біодеградації $[5,7]$ антигельмінтики і кокцидіостатики [6]. Це веде до деградації водних екосистем, що негативно впливає на гідробіонтів $[9,12]$.

Особливе занепокоєння викликає наявність у воді річок естрогенів і андрогенів та їх кон'югатів $[10,11]$, серед яких знайдено також і 19-нортестостерон (нандролон) [7]. Це синтетичний стероїд, який широко використовується як терапевтичний засіб та стимулятор продуктивності тварин, входить до групи прогестерону і вливає на процеси травлення та стимулює метаболічні процеси у тканинах тварин $[13,14]$. У стічних водах виявлено і продукти деградації нандролону 19-норадростерон, 19-норетіхоланолон та 5-дигідро-19-нортестостерон (дигідронандролон), які також володіють гормональною активністю в організмі [13].

Стічні води також містять антигельмінтик альбендазол - основний протипаразитарний препарат, який належить до групи бензімідазолу [14]. Альбендазол викликає у паразитів дегенеративні зміни клітинних мембран шляхом гальмування процесу полімеризації тубуліну. Це веде до зникнення мікротубул цитоплазми клітин паразита та його загибелі $[15,16]$.

Крім того, альбедазол є інгібітором ацтилхолінестерази та володіє нейротоксичною дією в організмі тварин. Метаболізується він частково в печінці з утворенням сульфоксидальбендазолу та сульфональбендазолу [16].

Оскільки нандролон і альбендазол знайдено у стічних водах тваринницьких підпри- ємств, а їх дестабілізуючий вплив на фізіологічні процеси у гідробіонтів вивчено недостатньо, актуальними є дослідження фракційного складу білків крові риб, що дасть можливість поглибити уявлення про механізми їх адаптації до дії штучних ксенобіотиків антропогенного походження. Мета роботи - з'ясувати вплив ксенобіотиків різного механізму дії нанролону та альбендазолу на вміст і фракційний склад білків плазми крові коропа.

\section{Матеріали і методи}

Дослідження проведені в лабораторії кафедри загальної зоології та іхтіології Національного університету біоресурсів природокористування України. Об'єктом дослідження слугували дворічки коропа (Cyprinuscarpio L.), вирощені у ВАТ «Київрибгосп». Для проведення експериментів було відібрано 32 коропи масою тіла 450-500 г. При проведенні досліджень риб утримували в акваріумах з об'ємом води 40 літрів по 2 голови в кожному. У воді акваріумів у процесі експериментів підтримували оптимальні значення температури $\left(18-20^{\circ} \mathrm{C}\right)$ та вміст Оксигену (7-8 мг/л). Під час досліду, який тривав 72 години, риб не годували.

У першому досліді вивчали вплив різних концентрацій нандролону у воді на загальний вміст та фракційний склад білків плазми крові риб. 3 цією метою у воду першого акваріума перед посадкою риб додавали 4 мг (перша), другого - 20 мг (друга) і третього - 40 мг (третя дослідна група) нандролону (Sigma-Aldrich), що відповідало концентраціям 0,$1 ; 0,5$ i 1,0 мг/дм ${ }^{3}$ води. У воду четвертого акваріума, де утримували риб контрольної групи, нандролон не вносили.

У другому експерименті досліджували загальний вміст і фракційний склад білків плазми крові коропа за дії альбендазолу. Для цього у воду акваріумів об'ємом 40 л перед посадкою риб вносили альбендазол у кількості, що відповідала його концентрації 0,2 (перша), 0,5 (друга) і 1,0 мг/дм³ (третя дослідна група). Контрольну групу риб утримували у воді без альбендазолу. В процесі досліду спостерігали за поведінкою риб, контролюючи кількість дихальних рухів. 
Наприкінці досліду у коропів контрольної та дослідних груп відбирали кров, з якої одержували плазму та визначали в ній загальний вміст і фракційний склад білків. Після взяття крові проводили візуальні дослідження зовнішніх покривів тіла коропів (луски, плавців), а після розтину — стан внутрішніх органів, контролюючи їх розмір, колір, консистенцію, наявність геморагій та запалень [17]. Вміст білка в плазмі крові риб визначали за Gornely [18], а фракційний склад білків — за Leammly [19]. Білки плазми крові риб розділяли на фракції в поліакриламідному гелі 3 градієнтом концентрації 7-18\%, додаючи додецилсульфат натрію. Одержані гелі фіксували сумішшю розчинів метанол-формальдегід: вода у співвідношенні $6: 1: 7$ та фарбували $0,1 \%$ розчином кумасі R-250 (Serva, Швеція).

Молекулярну масу білків окремих білкових зон встановлювали за білками-маркерами (ThermoBioscience, Англія).

Одержані гелі сканували гель-сканером Hewlett-PackardHPSI 5500 (США) 3 подальшою їх графічною реконструкцією. Кількість білка в окремій зоні обчислювали за відносними (\%) та абсолютними (г/л) одиницями з урахуванням значення загального білка в пробі, використовуючи спеціальну комп'ютерну програму DensitoAnalyze [20]. Статистичну обробку результатів досліджень здійснено за допомогою комп'ютерної програми Microsoft Excel 2000 з використанням критерію вірогідності Стьюдента [21].

\section{Результати й обговорення}

Утримування риб у воді з концентрацією нандролону 0,1 і 0,5 мг/дм ${ }^{3}$ протягом 72 годин не впливало на їх поведінку, кількість дихальних рухів та патоморфологічні показники внутрішніх органів. Стан зовнішніх покривів тіла, а також розмір, колір, консистенція внутрішніх органів, а саме гепатопанкреасу, слизової оболонки кишечнику, нирок, а також зябрових пелюсток у риб дослідних груп не відрізнялись від контролю.

У риб першої та третьої дослідних груп встановлено підвищення загального вмісту білків в плазмі крові в середньому в 1,5 разу, тоді як у коропів другої дослідної групи цей показник, порівняно з контролем, зростав невірогід1но (Табл. 1).

У риб дослідних груп за дії нандролону встановлено зміну фракційного складу білків плазми крові. У коропів, яких утримували у воді з концентрацією нандролону

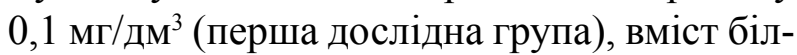
ків у плазмі крові 3 молекулярною масою 100 140 кДа (зона Е) і 35-50 кДа (зона L) збільшився, відповідно, на 54 і 43 \%, а вміст білків 3 масою молекул 25 кДа (зона Р) - на $75 \%$ порівняно $з$ контролем (Табл. 2).

Вміст білків в плазмі крові риб першої дослідної групи з молекулярною масою 140-450 кДа і вище (зона А, В, С, D), до яких входять й імунні глобуліни, не змінювався порівняно з контролем, на відміну від рів-

Табличя 1

Загальний вміст білка в плазмі крові коропа за дії нандролону та альбендазолу, г/л $(\mathbf{M} \pm \mathbf{m} ; n=4)$

Content of total protein in the blood plasma of carp under influence of nandrolone and albedazole, $\mathrm{g} / \mathrm{l}(\mathrm{M} \pm \mathbf{m} ; \mathrm{n}=\mathbf{4})$

\begin{tabular}{|l|c|c|}
\hline \multirow{2}{*}{$\begin{array}{c}\text { Група } \\
\text { Group }\end{array}$} & \multicolumn{2}{|c|}{$\begin{array}{c}\text { Ксенобіотики } \\
\text { Хenobiotics }\end{array}$} \\
\cline { 2 - 3 } & $\begin{array}{c}\text { Нандролон } \\
\text { Nandrolone }\end{array}$ & $\begin{array}{c}\text { Альбендазол } \\
\text { Albendazole }\end{array}$ \\
\hline Контрольна (Control) & $22,80 \pm 2,12$ & $20,28 \pm 2,29$ \\
\hline Дослідні (Research): & $34,83 \pm 2,07^{*}$ & $20,95 \pm 2,29$ \\
- перша (first) & $26,65 \pm 2,04$ & $17,05 \pm 1,28$ \\
- друга (second) & $34,00 \pm 1,19^{*}$ & $23,20 \pm 1,49$ \\
- третя (third)
\end{tabular}

Примітка: * — різниця вірогідна $(\mathrm{P} \leq 0,05)$ порівняно з контролем 
Фракційний склад білків плазми крові коропа за дії нандролону, г/л $(\mathrm{M} \pm \mathrm{m}, \mathrm{n}=4)$ Fractional composition of blood plasma proteins in carp under the influence of nandrolone, $g / l(M \pm m, n=4)$

\begin{tabular}{|c|c|c|c|c|c|}
\hline \multirow{2}{*}{$\begin{array}{l}\text { Зона } \\
\text { Zone }\end{array}$} & \multirow{2}{*}{$\begin{array}{c}\text { Молекулярна маса } \\
\text { стандартних білків, } \\
\text { кДа } \\
\text { Molecular weight of } \\
\text { standart proteins, kDa }\end{array}$} & \multirow{2}{*}{$\begin{array}{l}\text { Контрольна група } \\
\text { Control group }\end{array}$} & \multicolumn{3}{|c|}{$\begin{array}{c}\text { Дослідна група (концентрація нандролону у воді, мг/дм³) } \\
\text { Test group (nandrolone concentration in water, } \mathrm{mg} / \mathrm{dm}^{3} \text { ) }\end{array}$} \\
\hline & & & $\begin{array}{l}\text { перша }(0,1) \\
\text { first }(0,1)\end{array}$ & $\begin{array}{l}\text { друга }(0,5) \\
\text { second }(0,5)\end{array}$ & $\begin{array}{l}\text { третя }(1,0) \\
\text { third }(1,0)\end{array}$ \\
\hline A & $>450$ & $0,71 \pm 0,15$ & $0,72 \pm 0,26$ & $1,25 \pm 0,25^{*}$ & $1,36 \pm 0,13 *$ \\
\hline $\mathrm{B}$ & 340 & $1,01 \pm 0,29$ & $1,40 \pm 0,22$ & $1,15 \pm 0,25$ & $1,80 \pm 0,11 *$ \\
\hline $\mathrm{C}$ & 260 & $1,06 \pm 0,23$ & $0,98 \pm 0,93$ & $1,32 \pm 0,21$ & $2,13 \pm 0,16^{*}$ \\
\hline $\mathrm{D}$ & 140 & $1,40 \pm 0,27$ & $1,80 \pm 0,28$ & $1,46 \pm 0,40$ & $2,18 \pm 0,32 *$ \\
\hline $\mathrm{E}$ & - & $0,92 \pm 0,12$ & $1,42 \pm 0,14^{*}$ & $1,13 \pm 0,33$ & $1,04 \pm 0,21$ \\
\hline $\mathrm{F}$ & 100 & $1,01 \pm 0,37$ & $1,88 \pm 0,44$ & $1,16 \pm 0,31$ & $1,27 \pm 0,09$ \\
\hline G & - & $1,32 \pm 0,71$ & $1,89 \pm 0,26$ & $1,46 \pm 0,38$ & $1,01 \pm 0,17$ \\
\hline $\mathrm{H}$ & 70 & $0,55 \pm 0,25$ & $1,14 \pm 0,23$ & $0,64 \pm 0,18$ & $1,37 \pm 0,25^{*}$ \\
\hline $\mathrm{J}$ & - & $1,31 \pm 0,55$ & $1,89 \pm 0,22$ & $1,39 \pm 0,40$ & $1,28 \pm 0,97$ \\
\hline $\mathrm{K}$ & 50 & $2,83 \pm 0,60$ & $4,03 \pm 0,33$ & $3,33 \pm 0,53$ & $5,98 \pm 1,15^{*}$ \\
\hline $\mathrm{L}$ & - & $2,32 \pm 0,25$ & $3,32 \pm 0,37^{*}$ & $2,97 \pm 0,72$ & $2,70 \pm 0,34$ \\
\hline $\mathrm{M}$ & - & $3,13 \pm 0,49$ & $4,75 \pm 0,84$ & $3,86 \pm 0,51$ & $4,04 \pm 0,59$ \\
\hline $\mathrm{N}$ & 35 & $0,71 \pm 0,32$ & $1,18 \pm 0,31$ & $0,76 \pm 0,14$ & $0,88 \pm 0,13$ \\
\hline $\mathrm{O}$ & - & $0,69 \pm 0,13$ & $1,19 \pm 0,29$ & $0,70 \pm 0,29$ & $0,93 \pm 0,24 *$ \\
\hline $\mathrm{P}$ & 25 & $4,53 \pm 0,71$ & $7,92 \pm 0,69 *$ & $5,32 \pm 0,48$ & $7,35 \pm 0,32 *$ \\
\hline
\end{tabular}

Примітка: * — різниця вірогідна $(\mathrm{P} \leq 0,05)$ порівняно з контролем)

Таблиця 3

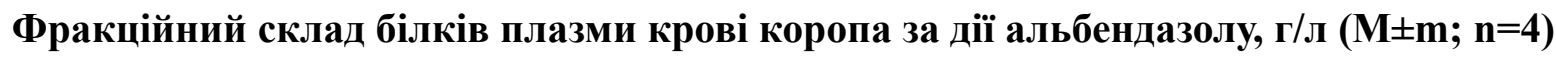
Fractional composition of blood plasma proteins in carp under the influence of albendazole, $g / l(M \pm m ; n=4)$

\begin{tabular}{|c|c|c|c|c|c|}
\hline \multirow{2}{*}{$\begin{array}{l}\text { Зона } \\
\text { Zone }\end{array}$} & \multirow{2}{*}{$\begin{array}{c}\text { Молекулярна маса } \\
\text { стандартних білків, } \\
\text { кДа } \\
\text { Molecular weight of } \\
\text { standart proteins, kDa }\end{array}$} & \multirow{2}{*}{$\begin{array}{c}\text { Контрольна група } \\
\text { Control group }\end{array}$} & \multicolumn{3}{|c|}{$\begin{array}{c}\text { Дослідна група (концентрація альбендазолу у воді, мг/дм³) } \\
\text { Test group (albendazole concentration in water, } \mathrm{mg} / \mathrm{dm}^{3} \text { ) }\end{array}$} \\
\hline & & & $\begin{array}{l}\text { перша }(0,2) \\
\text { first }(0,2)\end{array}$ & $\begin{array}{c}\text { друга }(0,5) \\
\text { second }(0,5)\end{array}$ & $\begin{array}{l}\text { третя }(1,0) \\
\text { third }(1,0)\end{array}$ \\
\hline A & $>450$ & $1,36 \pm 0,13$ & $0,85 \pm 0,35$ & $0,77 \pm 0,08 *$ & $0,85 \pm 0,21 *$ \\
\hline $\mathrm{B}$ & 340 & $1,80 \pm 0,11$ & $0,96 \pm 0,25$ & $0,80 \pm 0,09 *$ & $1,15 \pm 0,08^{*}$ \\
\hline $\mathrm{C}$ & 260 & $2,13 \pm 0,16$ & $0,88 \pm 0,30$ & $0,81 \pm 0,12 *$ & $1,17 \pm 0,03 *$ \\
\hline $\mathrm{D}$ & 140 & $2,18 \pm 0,32$ & $1,00 \pm 0,42$ & $0,81 \pm 0,11 *$ & $0,95 \pm 0,05 *$ \\
\hline $\mathrm{E}$ & - & $1,09 \pm 0,21$ & $0,75 \pm 0,23$ & $0,73 \pm 0,20$ & $0,87 \pm 0,08$ \\
\hline $\mathrm{F}$ & 100 & $1,27 \pm 0,99$ & $0,82 \pm 0,27$ & $1,08 \pm 0,11$ & $1,39 \pm 0,16$ \\
\hline $\mathrm{G}$ & - & $1,91 \pm 0,17$ & $0,86 \pm 0,33$ & $0,85 \pm 0,16$ & $0,92 \pm 0,05$ \\
\hline $\mathrm{H}$ & 70 & $1,37 \pm 0,38$ & $0,31 \pm 0,11 *$ & $0,33 \pm 0,04^{*}$ & $1,33 \pm 0,27 * *$ \\
\hline $\mathrm{J}$ & - & $1,28 \pm 0,07$ & $2,08 \pm 0,79$ & $0,84 \pm 0,11 *$ & $1,32 \pm 0,18$ \\
\hline K & 50 & $5,98 \pm 0,45$ & $2,350,37^{*}$ & $2,05 \pm 0,41 *$ & $2,74 \pm 0,26^{*}$ \\
\hline $\mathrm{L}$ & - & $2,70 \pm 0,34$ & $2,29 \pm 0,35$ & $1,73 \pm 0,28 *$ & $2,19 \pm 0,33$ \\
\hline M & - & $4,04 \pm 0,39$ & $3,04 \pm 0,56$ & $2,23 \pm 0,34 *$ & $2,63 \pm 0,21 *$ \\
\hline $\mathrm{N}$ & 35 & $0,88 \pm 0,13$ & $0,55 \pm 0,21$ & $0,50 \pm 0,09$ & $0,58 \pm 0,10^{*}$ \\
\hline $\mathrm{O}$ & - & $0,93 \pm 0,14$ & $0,54 \pm 0,18$ & $0,57 \pm 0,11$ & $0,77 \pm 0,25$ \\
\hline $\mathrm{P}$ & 25 & $7,35 \pm 0,32$ & $3,82 \pm 0,41 *$ & $3,71 \pm 0,38 *$ & $5,19 \pm 0,35^{* * *}$ \\
\hline
\end{tabular}

Примітка: * — різниця вірогідна $(\mathrm{P} \leq 0,05)$ порівняно 3 контролем, ** — різниця вірогідна $(\mathrm{P} \leq 0,05)$ порівняно з другою дослідною групою 
ня низькомолекулярних білків (зона L, O, P) (див. Табл. 2). Отже, нандролон у незначній концентрації у воді підвищує вміст низькомолекулярних білків і деяких білків з молекулярною масою 100 кДа у плазмі крові коропів, проте не впливає на рівень білків з високою молекулярною масою.

Підвищення концентрації нандролону у воді до 0,5 мг/дм ${ }^{3}$ не вплинуло на фракційний склад білків крові коропів другої дослідної групи порівняно з контролем, за винятком білків зони А, вміст яких зріс на $74 \%$ (Табл. 2). Рівень білків з високою (зони В, С, D), середньою (зони E, F, G, H) та низькою молекулярною масою (зони J, K, L, M, N, O, P) у плазмі крові коропів другої дослідної групи не змінювався порівняно з контролем. Більш суттєві зміни білкового спектру плазми крові зареєстровано у риб третьої дослідної групи, розміщені як в зоні високомолекулярних, так i білків із низькою молекулярною масою.

Так, рівень білків з молекулярною масою 450 кДа і вище у плазмі крові риб третьої дослідної групи (зона А), порівняно з контролем, збільшився на 91 \% , 340 кДа (зона В) на 78 \%, 260 кДа (зона С) 一 на $101 \%, 70$ кДа (зона Н) - на $149 \%, 50$ кДа (зона К) 一 на $111 \%$, зони О - на 35 \% і 25 кДа (зона Р) на $62 \%$. Вміст інших білків в плазмі крові риб третьої дослідної групи, порівняно з контролем, практично не змінювався.

Отже, за концентрації нандролону 1,0 мг/дм ${ }^{3}$ у воді акваріума білковий спектр плазми крові коропа змінюється значною мірою навіть за умови його нетривалої дії, що вказує на суттєвий вплив цього ксенобіотика на біосинтетичні процеси у тканинах як анаболічногостероїда.

Характер змін білкового спектру плазми крові риб за дії антигельмінтика альбендазолу був дещо іншим порівняно 3 нандролоном.

Варто зазначити, що за різної концентрації альбендазолу у воді та нетривалої дії кількість дихальних рухів, поведінка, поверхня тіла, патоморфологічні показники основних внутрішніх органів у риб дослідних груп не відрізнялись від контролю. Не виявлено також вірогідної різниці і за вмістом загального білка у плазмі крові риб дослідних груп порівняно з контролем (Табл. 1).

Витримування коропів впродовж 72 годин в акваріумі з водою, концентрація альбендазолу в якій становила 0,2 мг/дм³ (перша дослідна група), впливало лише на вміст деяких білків плазми крові риб. Зокрема зареєстровано зниження в плазмі крові риб рівня протеїнів з молекулярною масою 70 кДа на $77 \%, 50$ кДа - на $61 \%$ і 25 кДа - на $48 \%$ порівняно з контролем (Табл. 3). Вміст білків високомолекулярних фракцій, зокрема 3 молекулярною масою 100 кДа і вище, а також інших низькомолекулярних білків у плазмі крові риб першої дослідної групи не відрізнявся від контролю. Підвищення концентрації альбендазолу у воді акваріума до $0,5 \mathrm{мг} /$ дм $^{3}$ більшою мірою впливало на білковий спектр плази крові риб, про що свідчить зниження рівня білків, розміщених в зонах $\mathrm{A}, \mathrm{B}, \mathrm{C}, \mathrm{D}$, зокрема з молекулярною масою 140 кДа на $63 \%, 260$ кДа — на $62 \%, 340$ кДа - на $55 \%$ і 450 кДа і більше - на 43 \% порівняно $з$ контролем (див. Табл. 3). У плазмі крові цієї групи риб зареєстровано також зниження рівня білків з молекулярною масою 70 кДа на $76 \%$, білків в зоні $\mathrm{J}$ - на $34 \%$, у зоні K 3 молекулярною масою 50 кДа - на $66 \%$, в зоні L- - а $36 \%$,в зоні М - на $45 \%$ і в зоні P 3 молекулярною масою 25 кДа - на 49 \% порівняно з аналогічними показниками у риб контрольної групи. Вміст білків інших фракцій у плазмі крові риб другої дослідної групи за дії альбендазолу порівняно з контролем не змінювався.

Подібні зміни білкового спектру плазми крові риб зареєстровано і в коропів третьої дослідної групи, які протягом 72 годин перебували в акваріумі з концентрацією антигельмінтика 1,0 мг/дм³ води. Так, рівень білків плазми крові у цієї групи, розміщених у зонах A, B, C і D, що відповідає молекулярній масі 140, 260, 340, 450 кДа і вище, знизився, відповідно, на 56, 36, 36 і 37 \% порівняно з контролем (Табл. 3). Крім того, у риб третьої дослідної групи, порівняно з контролем, альбендазол викликав зниження у плазмі крові рівня білків з молекулярною масою 50 кДа (зона К) на 54 \%, з молекулярною ма- 
сою 35 кДа (зона N) - на 34 \%, 3 молекулярною масою 35 кДа (зона Р) - на 29 \%. Інші білки плазми крові риб за підвищеної дози альбендазолу до 1,0 мг/дм³ у воді акваріума змінювались значно меншою мірою.

Слід зазначити, що альбендазол, як і нандролон, додані у воду акваріумів у незначній концентрації, за нетривалої експозиції практично не впливали на електрофоретичну рухливість білків плазми крові риб, що, можливо, пов'язано із відсутністю їх впливу на заряд білкової молекули.

Вміст білків деяких інших фракцій у плазмі крові риб третьої дослідної групи, порівняно $з$ другою, збільшився і досяг значень аналогічних показників у коропів контрольної групи. Так, вміст білків у плазмі крові риб третьої дослідної групи з молекулярною масою 70 кДа (зона Н) зріс на $303 \%$, а з молекулярною масою 25 кДа (зона Р) - на $40 \%$ порівняно з аналогічними показниками у коропів другої дослідної групи (Табл. 3). Суттєвої різниці за фракційним складом інших білків плазми крові риб другої і третьої дослідних груп не встановлено попри те, що концентрацію альбендазолу у воді акваріума для останньої було збільшено вдвічі. Виявлена в дослідженнях різниця за вмістом білків плазми крові риб котрольних груп у першому та другому дослідах повязана, ймовірно, з різним вмістом загального білка плазми крові, а також з індивідуальними особливостями коропів.

Отже, результати досліджень вказують на те, що альбендазол у концентрації 0,2 мг/дм у воді акваріума не вливає, а у високих $(0,5$ i 1,0 мг/дм $\left.{ }^{3}\right)$ - знижує вміст білків як високо-, так і низькомолекулярних фракцій у плазмі крові коропа.

\section{Висновки}

За вмісту нандролону у воді $0,1 \mathrm{i}$ $0,5 \mathrm{мг} /$ дм $^{3}$, а альбендазолу - 0,2 мг/дм ${ }^{3}$ при експозиції коропів 72 години, незважаючи на різні механізми їх впливу на організм, білковий спектр плазми крові та загальний вміст білків залишається незмінним, що свідчить про здатність риб адаптуватись до дії незначних концентрацій цих ксенобіотиків. Високі концентрації цих ксенобіотиків у воді, зокрема нандролону 1,0 мг/дм ${ }^{3}$ та альбендазолу 0,5 i 1,0 мг/дм³ ${ }^{3}$ навіть за нетривалого перебування риб в акваріумі суттєво змінюють фракційний склад білків плазми крові дворічок коропа: нандролон підвищує, а альбендазол знижує вміст низки білків високо- та низькомолекулярних фракцій.

\section{Перспективи подалыших досліджень.}

Вивчення впливу нандролону та альбендазолу на вміст окремих класів імуноглобулінів, показники резистентності організму риб, що дасть можливість поглибити розуміння механізмів їх адаптації до дії ксенобіотиків антропогенного походження та доповнити екологічну характеристику водойм рибогосподарського призначення.

1. Belfroid A. C., Horst A., Vander Vethaak A. D., Schafer A. J., Rij G. B. J., Wegener J., Cofino W. P. Analysis and occurrence of estrogenic hormones and their glucuronides in surface water and wast Water in the Netherlands. The Science of the Total Environmental, 1999, Vol. 225, pp. 101-108.

2. Tanaka H., Yakou Y., Takahashi A., Komori K., Okayasu Y. Evaluation of environmental estrogens in Japanese. Water Science and Technology, 2001, WEFTEC 2001: Session 51 through Session 60, pp. 632-651 (20).

3. Ching-Hua Huang., David L. Sedlak. Analysis of estrogenic hormones in municipal wastewater effluent and surfaces water using enzymelinked immunosorbent ussey and gas ekromography /tandem mass spectrometry/. Environmental toxicology and chemistry, 2001, Vol. 20, no. 1, pp. 133-139.

4. Gulkowska A., Leung H. W., Yamashita N. Removal of antibiotics from wastewater by sewage treatment facilities in Hong Kong and Sheuzhen, China. Water research, 2008, vol. 42 (1-2), pp. 395-403.

5. Bradley P., Barber F., Cray, J. Biodegradation of 17-Estradiol, Estrone and Testosterone in stream Sediments. Environmental Science of Technology, 2009, Vol. 43 (13), pp. 1902-1910.

6. Ivanova A., Zakharenko N. Sanitary-hygienic evaluation of waste water livestock enterprises. Veterinary Biotechnology, 2010, № 18, p. 77.

7. Ivanova A., Zakharenko N. Sanitary sewage indicators pig enterprises for biological purification methods. Scientific Bulletin of Lviv National University of Veterinary Medicine and Biotechnologies. 2013, № 3 (57), pp. 335-341.(in Ukrainian)

8. Ivanova A., Novozhytska Y., Zakharenko N, Shevchenko L. Feature sac cumulation Nandrolone and its metabolites in organ sand tissues of rats. Vet- 
erinary Medicine of Ukraine. 2011, № 6. pp. 40-42. (in Ukrainian)

9. Yasojima Makoto, Kobayashi Yoshikazy, Nakacva Norihide, Komori Koya, Suzuki Yutaka, Tanake Hiroaki. Behavior of Human Antibioticsin Wastewater Treatment Plants. Environmental Engineering Research, 2005, vol. 42, pp. 358-368.

10. Takuma Furuichi, Kurunthacha Lamkanna. Occurrence of Estrogenic Compoundsin and Removal by a Swine Farm Waste Treatment Plant. Environmental Science of Technology, 2006, Vol. 40, pp. 7896-7902.

11. Fine D. D., Breidenbach G. P., Price T. L., Hutchins S. R. Quantification of estrogen in groundwater and swine lagoon samples using solid phase extraction, pentafluorobenzyltrimetylsilylduivatizatvions and gas chromatogryfhy-negativ ion chemical ionization tandem mass spertrometry. Chromatogryfhy, 2003, Vol. 1017 (1-2), pp. 167-185.

12. Kurbatova I., Tsedyk V. The quality of the water reservoirs of industrial fishing and its impact on the eggs of carp (Cyprinuscarpio L.).Scientific works of Volyn National University, 2012, № 9, pp. 224-228. (in Ukrainian)

13. Kurbatova I., Tupytska O.,Tsedyk V. Transamination enzyme activity and some chemical parameters of blood carp (Cyprinuscarpio L.) for the actions set xenobiotics. Proceedings of Kalininhrad state technical university, 2014, № 33, pp. 11-15. (in Russian)
14. Ivanova A. Hygienic assessment juices pig enterprises containing drugs and steroid hormones: dissertation thesis the candidate degree veterinary sciences: specialty 16.00.06 "Animal Hygiene and Veterinary Sanitation". Kyiv, 2014, 21 p. (in Ukrainian)

15. Tafiychuks R. Analysis of the frequency of micronuclei in erythrocytes carp for the actions of an thelmintics. Scientific Bulletin of Lviv National University of Veterinary Medicine and Biotechnologies, 2008, T. 10, № 3 (38), pp. 250-252. (in Ukrainian)

16. Prikhodko Y. Effect of albendazole on protein and carbohydrate metabolism and the state of humoral immunity pigs. VeterinaryMedicine, 2000, Vol. 78 (II), pp. 178-181. (in Ukrainian)

17. Baklashova T. Workshop on the ichthyology. Moscow, Agropromizdat, 1990, 223 p. (in Russian)

18. Gornely S. Determination of serum protein by mean of biuret reaction. Journal of Biology Chemistry, 1949, Vol. 177, no. 177, pp. 751-755.

19. Laemmly U. K. Cleavage of structural proteins during the assembly of the head of Bacteriophage $\mathrm{T}_{4}$. Nature, 1970 , Vol. 227 , no. 5259, pp. 680-685.

20. Bondarenko S., Golovin A., Dmytrenko M., Yurchenko A., Babicheva A. Computed registration and analysis of TLC. Chromatography Journal of the Society, 2003, Vol. 2, № 4, pp. 22-30. (in Ukrainian)

21. Kokunin V. A. Statistical data processing with a small number of experiments. Ukrain. biochem. Journal, 1975, Vol. 47, № 6, pp. 776-790. (in Ukrainian) 